\title{
THE NEW ORIGINALIST MANIFESTO
}

\section{CONSTITUTIONAL ORIGINALISM: A DEBATE.}

Lawrence B. Solum ${ }^{1}$ and Robert W. Bennett. ${ }^{2}$ Ithaca: Cornell University Press. 2011. Pp. ix + 210. \$29.95 (Cloth).

\section{James E. Fleming ${ }^{3}$}

\section{INTRODUCTION}

Lawrence B. Solum and Robert W. Bennett's excellent book, Constitutional Originalism: A Debate, calls to mind a famous book in political philosophy, J.J.C. Smart and Bernard Williams's Utilitarianism: For and Against. ${ }^{4}$ Both works pair two spirited yet fair-minded scholars in a constructive debate between two competing views prevalent in their fields. Originalism has a reasonable, programmatic, and inclusive proponent in Solum, and living constitutionalism has a capable, pragmatic, and effective champion in Bennett.

In this essay, I shall not judge the debate between Solum and Bennett. Instead, I shall focus on Solum's contribution, interpreting it as a new originalist manifesto. I shall extend the debate, carrying on what I believe is an equally important debate between originalism and what Ronald Dworkin called a "moral reading" of the Constitution and what I call a "Constitutionperfecting theory." Some readers may think that Dworkin's and

1. John Carroll Research Professor of Law, Georgetown University Law Center. School.

2. Nathaniel L. Nathanson Professor of Law, Northwestern University Law

3. Professor of Law, The Honorable Frank R. Kenison Distinguished Scholar in Law, and Associate Dean for Research and Intellectual Life, Boston University School of Law. In Part IV, I incorporate a paper I presented at a panel on "The Original Meaning of the Privileges or Immunities Clause," held at the Annual Meeting of the Law and Society Association, Denver, May 28, 2009. The panel, coincidentally, was organized by Larry Solum and included discussion with Larry and Randy Barnett about original public meaning originalism. Thanks to Courtney Gesualdi for help with this piece.

4. J.J.C. SMART \& BERNARD WILLIAMS, UTILITARIANISM: FOR AND AGAINST (1973).

5. Ronald Dworkin, Freedom's Law: THE MORal Reading of the AMERICAN CONSTITUTION 2-3 (1996); JAMES E. FlEMING, SECURING CONSTITUTIONAL DEMOCRACY: THE CASE OF AUTONOMY 16, 210-11 (2006). 
my approaches are versions of living constitutionalism, but they are importantly different from it. I shall suggest that the prospects for reconciliation between Solum's new originalism and moral readings are greater than those between his new originalism and living constitutionalism. The basic reason is that the new originalists and moral readers share a commitment to constitutional fidelity: to interpretation and construction that best fits and justifies the Constitution. Living constitutionalists characteristically are more pragmatic, instrumentalist, and forward-looking in their approaches to the Constitution and, as such, tend to be anti-fidelity. This essay will further my book in progress, Fidelity to Our Imperfect Constitution, which defends a moral reading or Constitution-perfecting theory as a conception of constitutional fidelity that is superior to originalism, however conceived.

At the outset, I should say that Solum is the ideal scholar for the project of writing a new originalist manifesto. He fairly concedes many of the flaws in the old originalism, with an openness to criticism and a generosity of spirit that are not always present in originalists. He candidly grants that originalism has evolved-that it is a family of theories rather than one coherent, unified view - and that the new originalism is a work in progress (pp. 2, 7-11). He formulates the new originalism inclusively, seeking and articulating common ground among competing theories in a constructive spirit. Solum is somewhat unusual in not coming to his originalism for political reasons. Many conservatives appear to embrace originalism because they believe that it will support conservative outcomes. And many liberals evidently adopt and adapt originalism because they believe that it is their best hope to persuade conservative judges: if you can't beat them, join them. Solum has neither motivation. He seems to come to his new originalism out of philosophic and jurisprudential commitments - not to wage a counter-revolution against the liberal Warren Court, but to correct the philosophical and jurisprudential excesses and errors of Legal Realism and Critical Legal Studies. As a matter of principle, he wants to get the theory of interpretation and construction right. For these reasons, his project has an admirable and demonstrable integrity.

In Part I, I evaluate the claim implicit in the title of Solum's opening chapter, "We Are All Originalists Now." In Part II, I

6. James E. Fleming, Fidelity to Our Imperfect CONSTITUTion (under contract with Oxford University Press) (on file with author). 
explicate Solum's formulation of the new originalism by contrasting it with Keith Whittington's. In Part III, I explore Solum's development of the distinction between interpretation and construction. In Part IV, I show the misconceived quest for the original public meaning. In Part V, I take up the possibility of reconciliation between the new originalism and living constitutionalism, suggesting that such prospects are better for the new originalism and moral readings. Finally, in Part VI, I make explicit the missing (or implicit) argument for the new originalism from constitutional perfectionism: an argument deriving from the aspiration to fidelity to our imperfect Constitution.

\section{ARE WE ALL ORIGINALISTS NOW? EVIDENTLY SO, YET DEFINITELY NOT!}

In recent years, many have posed the question, "Are we all originalists now?" In response, I have written an article entitled, Are We All Originalists Now? I Hope Not!' By contrast, Solum replies with his title, We Are All Originalists Now (p. 1). The answer to the question depends, as he recognizes, on "what one means by originalism" and whether we define it exclusively or inclusively (pp. 61-62) (emphasis in the original).

In defining originalism, Solum distills an elegant framework with four basic ideas. It is worth quoting in full:

- The fixation thesis: The linguistic meaning of the constitutional text was fixed at the time each provision was framed and ratified.

- The public meaning thesis: Constitutional meaning is fixed by the understanding of the words and phrases and the grammar and syntax that characterized the linguistic practices of the public and not by the intentions of the framers.

- The textual constraint thesis: The original meaning of the text of the Constitution has legal force: the text is law and not a mere symbol.

- The interpretation-construction distinction: Constitutional practice includes two distinct activities: (1) constitutional interpretation, which discerns the linguistic meaning of

7. James E. Fleming, Are We All Originalists Now? I Hope Not!, 92 TEX. L. REV. (forthcoming 2013). 
the text, and (2) constitutional construction, which determines the legal effect of the text. (p. 4)

Solum aspires to understand originalism (and, for that matter, living constitutionalism) "in their best light-in their most sophisticated and defensible versions" (p. 5). I shall come back to this Dworkinian-sounding formulation at the end.

If we define originalism inclusively enough, we might say that we evidently are all originalists now. Indeed, we might just define originalism so broadly that even I would no longer hope that we are not all originalists now! Applying Solum's framework, we would conclude that Jack Balkin, with his selfdescribed living originalist method of text and principle, definitely is a new originalist. ${ }^{8}$ Ronald Dworkin, with his moral reading of the Constitution, surely also is." Sotirios A. Barber and I, with our philosophic approach to constitutional interpretation (and my own "Constitution-perfecting theory"), are as well..$^{10}$ So, too, are reasonable, bounded, and grounded versions of living constitutionalism. All of these theories evidently can accept the four theses quoted above. Under Solum's formulation, originalism clearly is a big tent-charitable, magnanimous, and inclusionary-rather than the dogmatic, scolding, and exclusionary outlook that we see in originalist works like Robert Bork's The Tempting of America and Antonin Scalia's A Matter of Interpretation."

But if we define originalism so inclusively - and we are all now in this big tent-it may not be very useful to say that we are all originalists now. We may obscure our differences more than elucidating common ground. For we would persist in most of our theoretical disagreements - it is just that we would say that the disagreements are among varieties of so-called originalism. And the debates concerning interpretation and construction, thus recast or translated, would go on much as before.

Despite the implication of his title, Solum's own analysis refutes the claim that we are all originalists now. Who, from the standpoint of his framework, is not a new originalist? First, the old originalists are not. As Solum acknowledges, they reject the

8. See JACK M. BALKin, Living Originalism (2011).

9. See DWORKIN, supra note 5.

10. See Sotirios A. Barber \& James E. Fleming, Constitutional InterPRETATION: THE BASIC QUESTIONS (2007); FLEMING, supra note 5.

11. Robert H. BORK, The Tempting of AMERica: THE POlitical Seduction OF THE LAW (1990): ANTONIN SCALIA, A MATTER OF INTERPRETATION: FEDERAL COURTS AND THE LAW (Amy Gutmann ed., 1997). 
public meaning thesis and the interpretation-construction distinction thesis (pp. 36, 53-54). For them, interpretation is a matter of discovering determinative intentions of the Framers and construction is illegitimate government by judiciary. Second, many contemporary originalists - those who might not style themselves old originalists but who reject the large role that the new originalism recognizes for construction-are not new originalists. Still, Solum does not exclude these two varieties from the big tent of originalism. He says that only two of the four commitments are necessary for originalism: the fixation thesis and the textual constraint thesis (pp. 35-36). Both of these varieties accept these two theses. And at one point, he refers to the "truism" of the fixation thesis and the "mundane[ness]" of the textual constraint thesis (pp. 53-54). Here, he implicitly admits just how thin and capacious these two theses are, and thus how big the tent of originalism is.

Third, despite Solum's magnanimous gestures toward reconciliation of the new originalism with living constitutionalism, he rejects many forms of the latter as beyond the pale. He criticizes strong forms of living constitutionalism growing out of Legal Realism or Critical Legal Studies precisely because they are not originalist, even in his capacious sense: they are pragmatic, instrumentalist, and forward-looking, rejecting even the relatively thin constraints that the new originalism would require of them (pp. 40, 50,74). For them, evidently, there is only construction; interpretation and construction are radically indeterminate. He attributes to such living constitutionalists the views that the text and original public meaning do not constrain interpretation and construction; that constitutional interpretation empowers judges to amend the Constitution; and that justice trumps the constitutional text (pp. 19-20, 47-49, 60). He ridicules many "so-called theories" of living constitutionalism as not being "real theories" but instead "pale imitations, mere gestures and hints" (pp. 74-75). In fact, despite the generally inclusionary tone of Solum's work, I have not seen such spirited attacks on living constitutionalism since reading Bork's The Tempting of America and Scalia's A Matter of Interpretation. ${ }^{12}$

Thus, when all is said and done, according to Solum himself, we definitely are not all originalists now.

12. BORK, supra note 11 at 167 ; SCALIA, supra note 11 , at $38-47,144-49$. 


\section{THE NEW ORIGINALISMS}

Next, I shall explicate Solum's understanding of the new originalism by contrasting it with Whittington's.

\section{A. What IS THE NeW ORIGINAliSM? TAKE ONE: WHITTINGTON}

What is the new originalism? This question presupposes three prior questions: What is the old originalism? Who are the old originalists? And why have many constitutional scholars and jurists sought to move beyond old originalism to the new originalism?

What? The old originalism is an ism-a conservative ideology that emerged in reaction to the Warren Court (and early Burger Court). Before President Richard Nixon and Professor Robert Bork launched their attacks on the Court, originalism as we now know it did not exist. Constitutional interpretation in light of original understanding ${ }^{13}$ did exist, but original understanding was seen as merely one source of constitutional decision making among several-not as a general theory of constitutional interpretation, much less the exclusive legitimate theory. The old originalists conceive original understanding in terms of concrete intentions of the Framers or their original expected applications. Accordingly, they argue that fidelity in constitutional interpretation requires following the rules laid down by, or giving effect to the relatively specific original understanding of, the Framers of the Constitution. And they argue that these concrete intentions or original expected applications are determinative concerning constitutional doctrine.

Who? The old originalists include, most prominently, Bork and Raoul Berger. ${ }^{14}$

Why? The old originalism is vulnerable to dispositive criticisms. In his book, Constitutional Interpretation, Keith Whittington has forthrightly addressed many of these criticisms, for example, that it was circular, question-begging, and axiomatic.

13. In using the word "original understanding," I am not expressing a position on the debates between intention of the Framers originalism and original public meaning originalism. I am using it as a generic term.

14. See, e.g., Raoul Berger, Government by Judiciary: The Transformation OF THE FOURTEENTH AMENDMENT (1977).

15. Keith E. Whittington, Constitutional interpretation: Textual 
What is the new originalism? Who are the new originalists? And what is new about their originalism? Whittington provides answers in offering a new originalism. Before reading his article on "The New Originalism," I I had thought that the new, improved originalists would be scholars and jurists who seek to reconstruct originalism to correct the theoretical flaws of the old originalism, or at least to bolster it against powerful criticisms.

But Whittington, with startling and refreshing frankness, provides a rather different account: He says that the new originalists are conservatives in power, whereas the old originalists were conservatives in the minority! $!^{17}$ His account of the old originalism is quite similar to mine: it emerged as a conservative reaction against the Warren Court. ${ }^{18}$ Now that conservatives have control of the judiciary, Whittington says, originalists need to move from being largely reactive and critical to developing "a governing philosophy appropriate to guide majority opinions, [and] not just fill dissents." originalism.

As a governing conservative constitutional theory, Whittington suggests, the new originalism "is less likely to emphasize a primary commitment to judicial restraint." ${ }^{20}$ Indeed. "First, there seems to be less emphasis on the capacity of originalism to limit the discretion of the judge." 21 "Second, there is also a loosening of the connection between originalism and judicial deference to legislative majorities." ${ }^{22}$ Instead, "[t]he primary virtue claimed by the new originalism is one of constitutional fidelity, not of judicial restraint or democratic majoritarianism." In sum, Whittington argues, "[t]he new originalism does not require that judges get out of the way of legislatures. It requires judges to uphold the original Constitution-nothing more, but also nothing less." ${ }^{24}$ (I shall return to these three arguments for, or asserted virtues of, originalism below.)

\footnotetext{
10 , at $92-93$.

17. Whittington, supra note 16, at 604 .

18. Id. at $599-602$

19. Id. at 604 .

20. Id. at 608 .

21. Id.

22. Id. at 609

23. Id. at 608-09.

24. Id.
}

MEANING, ORIGINAL INTENT, AND JUDICIAL REVIEW (1999).

16. Keith E. Whittington, The New Originalism, 2 GEO. J. L. \& PUB. POL'Y 599 (2004). Here I draw from my criticism of Whittington in BARBER \& FLEMING, supra note 


\section{B. What is THE NEW ORIGinalism? TAKE TwO: SOluM}

Solum's and Whittington's accounts of the old originalism are similar. And their accounts of the new originalism are similar in two respects. Solum's new originalism, like Whittington's, stresses: (1) original public meaning (as contrasted with the old originalists' emphasis on the intention of the Framers or their original expected applications), and (2) the significance of the distinction between interpretation and construction (as contrasted with the old originalists' rejection of construction as illegitimate) (p. 36).

But Solum's new originalism is significantly different. Whittington developed his new originalism to replace the old originalists' negative reaction against the liberal Warren Court with a governing constitutional theory for conservative judges, now that they are in power. Solum, by contrast, developed his new originalism to overcome the theoretical errors and excesses not only of the old originalists but also of Legal Realism and Critical Legal Studies. In fact, he wants to acknowledge the conservative ideology of the old originalists but to distance that from the new originalism as a constitutional theory, and not a political ideology (p. 64).

Moreover, Solum's new originalism really is a reconstruction to correct the theoretical flaws in the old originalism. He rejects most of the old originalists' conception of constitutional interpretation as indefensible (pp. 7-11, 20-22). He also repudiates the old originalists' conception of the Constitution as practically a code of determinate rules and concrete expected applications. On his understanding, original public meaning is more abstract, vague, and underdeterminedin part because he conceives some of the Constitution's commitments as general standards or abstract principles rather than as concrete, determinate rules (pp. 22, 24-25). Furthermore, Solum advances a very different understanding of construction than Whittington. For Whittington, at least in his initial formulation, interpretation is for judges and construction is for legislators and executives. ${ }^{25}$ For Solum, construction is also for judges in developing constitutional doctrine where interpretation is underdeterminate (pp. 22-24). Solum implicitly acknowledges this difference when he characterizes Whittington's view as the model of construction as politics (as

25. Keith E. Whittington, Constitutional Construction: Divided POWERS AND CONSTITUTIONAL MEANING 1-19 (1999). 
distinguished from Balkin's model of construction as principle): with courts deferring in the construction zone and letting political institutions do the construction (pp. 69-70). Below I suggest that there are similarities between Solum's and Balkin's conceptions of construction.

The upshot-to which I return-is that Solum's new originalism is more amenable to reconciliation with moral readings than is Whittington's.

In the next two sections, I assess Solum's new originalism in its own right, focusing on the significance of the distinction between interpretation and construction and the misconceived quest for the original public meaning.

\section{THE SIGNIFICANCE OF THE DISTINCTION BETWEEN INTERPRETATION AND CONSTRUCTION}

Let's be clear about what Solum claims about the significance of the distinction between interpretation and construction. In explaining this distinction, he invokes H.L.A. Hart's well-known formulation concerning the core and penumbra (p. 22). He presents the core as a zone for interpretation and the penumbra as a zone for construction. He contends that hard cases, by definition, are underdetermined by interpretation of original public meaning and so require construction (pp. 22-23).

Furthermore, Solum says that originalism is a theory of interpretation, not a theory of construction. In developing the interpretation-construction distinction, Solum plainly states: "Originalism itself does not have a theory of constitutional construction" (p. 60). He also states: "Whereof originalism cannot speak, thereof it must be silent" (p. 26). Even though construction in hard cases lies beyond interpretation (and thus beyond originalism), he claims that the new originalists insist that original public meaning should constrain construction (p. 26).

I shall make two general observations before going further into Solum's conception of construction. First, Solum concedes that much that is important in constitutional law goes on in the construction zone in deciding hard cases and developing constitutional doctrine. We might doubt how much of importance in constitutional law is resolved through interpretation of original public meaning (a point to which I return in showing the misconceived quest for the original public meaning). I suspect that Solum would find greater agreement with his 
analysis of interpretation and construction among living constitutionalists and moral readers than among most conventional originalists: for living constitutionalists and moral readers would agree that hard cases lie in the construction zone, and that interpretation of original public meaning does not determine the outcomes in these disputes. But old originalists and many other contemporary originalists would reject these claims as capitulations. Some, like the old originalists, would insist that interpretation is determinative both in deciding hard cases and developing constitutional doctrine (pp. 20-22). Others would deny the necessity or the legitimacy of construction. And some who accept the legitimacy of construction would go along with Whittington in adopting what Solum calls the model of construction as politics: they would say that interpretation is for courts and construction is for legislatures and executives (pp. 69$70)$.

Second, what Solum says about how construction should proceed-how he proposes to build out doctrine and decide hard cases in the construction zone-and about how original public meaning should constrain construction even if it does not determine it, is compatible with a moral reading. In defending this view, I shall focus on two things he says about originalism in relation to construction. One, Solum states: "originalists can and should agree that constitutional construction (as currently practiced) involves a plurality of methods-purposes, structure, precedent, and all the rest" (p. 60). He rejects the common living constitutionalist argument that the very existence of "multiple modalities" shows the impossibility of originalism (p. 59). He contends instead that "these methods are properly brought to bear on the task of constitutional construction" (p. 60). Thus, he practically makes peace with living constitutionalism concerning the multiple modalities of argument in the construction zone. Whittington recently has taken a similar approach in recognizing what he calls "pluralism within originalism" or how originalist arguments exist in an environment of "pluralism in constitutional interpretation" ${ }^{26}$ (or, Solum would insist, construction).

Two, Solum mentions three available models of construction as eligible within the new originalism (pp. 69-70).

26. Keith E. Whittington, On Pluralism within Originalism, in THE CHALLENGE OF ORIGINALISM: THEORIES OF CONSTITUTIONAL INTERPRETATION 70 (Grant Huscroft \& Bradley W. Miller eds., 2011). 
1. Construction as politics (associated with Whittington): "when judges leave the realm of constitutional interpretation and enter the construction zone, they defer to the decisions made by the political processes."

2. Construction as principle (associated with Balkin): "[i]n the construction zone, judges should aim to create constitutional doctrines that comport with political ideals for which the general, abstract, and vague provisions of the Constitution aim."

3. Construction by original methods (inspired by the work of John McGinnis and Michael Rappaport but not their own view): "when modern courts engage in constitutional construction, they should employ" the original methods in use when the Constitution was adopted.

Solum does not exactly say which model of construction is the most promising for the new originalism that he himself proposes. Doing so, I suppose, would be out of keeping with the spirit of an ecumenical new originalist manifesto. But, as stated above, there are significant differences between Whittington's model of construction as politics and Solum's approach to construction. For Whittington, again, interpretation is for judges and construction is for legislatures and executives. For Solum, by contrast, construction is also for judges in developing constitutional doctrine where interpretation is underdeterminative (pp. 22-23). Furthermore, it does not appear that Solum himself would emphasize construction by original methods. I interpret him as putting this model forward in the spirit of an inclusive manifesto rather than as advocating it as the best approach to construction. Finally, there is good reason to believe that Solum thinks that Balkin's model of construction as principle is the most promising approach for the new originalism that he himself advocates. What is more, Balkin's is the most promising model for a reconciliation of originalism and living constitutionalism; indeed, Balkin calls his new originalism "living originalism."

There is also considerable hope for reconciliation between the new originalism and moral readings regarding construction. First, moral readers like Barber and I deploy a fusion of approaches in what Solum calls "the construction zone." "Within such a fusion, we... understand text, consensus, intentions,

27. BALKIN, supra note 8 . 
structures, and doctrines not as alternatives to but as sites of philosophic reflection and choice about the best understanding of our constitutional commitments." 28 Second, moral readers should embrace Balkin's model of construction as the method of text and principle. In fact, I have argued that Balkin's theory is a moral reading of the Constitution. ${ }^{29}$ For Balkin conceives the Constitution as embodying not only rules but also general standards and abstract principles. ${ }^{30} \mathrm{He}$ recognizes that in interpreting these general standards and abstract principles, we have to make moral and political judgments concerning the best understanding of our commitments; history alone does not make those judgments for us in rule-like fashion. ${ }^{31}$ Moreover, there are unmistakable affinities between Balkin's commitment to interpret and construct the Constitution so as to redeem our faith in its promises and aspirations, and a moral reading's commitment to interpret and construct the Constitution so as to make it the best it can be. ${ }^{32}$

Thus, if Solum's new originalism embraces Balkin's method of text and principle-as an approach to interpretation and construction - it has much in common with a moral reading.

In the next section, I raise some doubts about Solum's new originalist quest for the original public meaning.

\section{THE MISCONCEIVED QUEST FOR THE ORIGINAL PUBLIC MEANING}

The inspiration for the title of this section is, of course, Paul Brest's classic article, "The Misconceived Quest for the Original Understanding., ${ }^{33}$ Solum refers to Brest's article at several points (pp. 8,14, 160). The new originalists may have reconceived the quest of the old originalists-from intention of the Framers or their original expected applications to original public meaning - but the new quest is likewise misconceived.

The quest for the original public meaning is misconceived because on most important provisions, there will not be a definitive original public meaning that will be useful in resolving

\footnotetext{
28. BARBER \& FLEMING, supra note 10 , at 190. $675-79$.

30. Id. at 676

31. BALKIN, supra note 8, at 23-34.

32. RONALD DWORKIN, LAW'S EMPIRE 255 (1986).

33. Paul Brest, The Misconceived Quest for the Original Understanding, 60 B.U. L. REV. 234 (1980).
} 
our disagreements, much less resolving hard cases. Let me give a hypothetical example of constitutional amendment and interpretation. Let's imagine that, in the near future, the Supreme Court overturns Lawrence v. Texas ${ }^{34}$-which had recognized a right of gays and lesbians to privacy or autonomyeven as our constitutional culture has accepted it, and has come not merely to tolerate but to respect gays and lesbians as equal citizens. Let's imagine that We the People then amend the Constitution by adopting the following Twenty-Eighth Amendment: "Well-ordered liberty being necessary to the happiness of a free state, the right to autonomy shall not be infringed."

How would debates about the original public meaning of the Twenty-Eighth Amendment likely proceed? Let's distinguish two quite different understandings, which parallel recognizable disagreements between originalists and moral readers of the Constitution. On the one hand, originalists like Scalia, who want to construe constitutional language specifically, might say that the original public meaning was simply, specifically, and exclusively to reinstate the narrow holding in Lawrence. Such originalists might say that the Twenty-Eighth Amendment protects only the right of gays and lesbians to engage in "deviate sexual intercourse," as the Texas statute invalidated in Lawrence had put it ${ }^{35}$ or the right of gays and lesbians to engage in "homosexual sodomy," as Justice White had put it in Bowers $v$. Hardwick, ${ }^{36}$ which was overruled in Lawrence. On their view, the Twenty-Eighth Amendment would be no more abstract a commitment to a right to autonomy than that. They would hold this view, not because they made an objective historical inquiry into original public meaning as a matter of empirical fact, but because of prior jurisprudential assumptions and commitments about what an original public meaning must be-and about the character of the Constitution, constitutional interpretation, and constitutional amendment. On their view, that evidently abstract language in the Twenty-Eighth Amendment simply has to embody specific meanings.

On the other hand, moral readers, who conceive the Constitution as a charter of abstract commitments, would likely say that the original public meaning was nothing less than to

34. Lawrence v. Texas, 539 U.S. 558 (2003).

35. Id. at 563 .

36. Bowers v. Hardwick, 478 U.S. 186, 191 (1986). 
ratify the right to autonomy that the Supreme Court had developed through the line of cases from Meyer and Pierce on through Griswold, Roe, Casey, and Lawrence. ${ }^{37}$ Moreover, they would claim that the original public meaning was to authorize the Supreme Court to go on as it had before in these cases elaborating our basic commitment to a right to autonomy. Indeed, they might go further and claim that the Constitution, properly interpreted, should protect whatever rights of autonomy we and the Supreme Court decide over time are essential to the concept of well-ordered liberty and autonomy. They would take this view, not because they made an objective historical inquiry into original public meaning as a matter of empirical fact, but because of prior jurisprudential assumptions and commitments about the character of the Constitution, constitutional interpretation, and constitutional amendment. On their view, that evidently abstract language in the Twenty-Eighth Amendment simply has to embody abstract commitments.

Let's observe that there would be no independent original public meaning - as a matter of history - that either side could resort to in order to definitively resolve their disagreements. Proponents of both understandings of the Twenty-Eighth Amendment would claim that their understandings were more faithful to the original public meaning. There would not be some definitive original public meaning of the words "right to autonomy" out there in our constitutional culture that would resolve our disputes-any more than there is a core public meaning of a right to autonomy out there right now. Furthermore, there is no lawyerly term of art, "right to autonomy," to which we could resort to resolve disagreement over the meaning of the right to autonomy. Those who are learned in the law vehemently disagree among themselves about it-along the lines sketched above-just as citizens disagree. So likewise it is with the Equal Protection Clause; the Due Process Clause; the Privileges or Immunities Clause; and the First Amendment's protections of freedom of speech, freedom of the press, and freedom of religion. So it is and ever shall be with significant constitutional provisions.

37. Lawrence, 539 U.S. 558; Planned Parenthood of Southeastern Pennsylvania v. Casey, 505 U.S. 833 (1992); Roe v. Wade, 410 U.S. 113 (1973); Griswold v. Connecticut, 381 U.S. 479 (1965); Pierce v. Society of the Sisters of the Holy Names of Jesus and Mary, 268 U.S. 510 (1925); Meyer v. Nebraska, 262 U.S. 390 (1923). See JAMES E. FLEMING \& Linda C. MCClain, ORdered LiberTy: Rights, Responsibilities, AND VIRTUES 244-67 (2013) (analyzing this line of cases protecting a "rational continuum" of ordered liberty). 
To make a further point about the misconceived quest for the original public meaning, I shall analyze the interpretation of the Privileges or Immunities Clause in the Slaughter-House Cases. ${ }^{3 \times}$ Many constitutional scholars and judges-including liberals and conservatives alike, originalists along with moral readers-believe that Slaughter-House was wrongly decided. Indeed, many believe that it was a travesty. And I'll bet that many, if they had a chance to overrule five decisions of the U.S. Supreme Court, would include Slaughter-House on their list. But I want to ponder for a moment the likely consequences of overruling Slaughter-House. I'll even put this in terms congenial to new originalists like Solum. Let's imagine that we overrule Slaughter-House and commit to return to the original public meaning of the Privileges or Immunities Clause (that's the part that is supposed to be congenial to the new originalists). And let's hypothesize that we agree that the original public meaning of the Privileges or Immunities Clause was that it was to protect the fundamental rights "which belong, of right, to the citizens of all free governments" (quoting Justice Bushrod Washington's famous formulation). ${ }^{39}$

What would be the likely consequence of overruling Slaughter-House and committing to carrying out the original public meaning so conceived? In all likelihood, precious little would change. (Sorry to prove to be so uncongenial to the new originalists after all.) Let me explain. The Supreme Court's gutting of the Privileges or Immunities Clause in SlaughterHouse did not stop the Court from interpreting the Fourteenth Amendment to protect fundamental rights essential to national citizenship (of the sort that by hypothesis it was the original public meaning of the Privileges or Immunities Clause to protect). As we all know, the Court turned to the word "liberty" in the Due Process Clause and to the Equal Protection Clause (the fundamental rights and interests strand) to do so.

For years, people have argued for reviving the Privileges or Immunities Clause, since its language (and original public meaning) more comfortably can bear the work of protecting fundamental rights essential to national citizenship. They also have argued that doing so would avoid common objections to using the Due Process and Equal Protection Clauses to protect

38. Slaughter-House Cases, 83 U.S. 36 (1872).

39. Corfield v. Coryell, 6 F. Cas. 546, 551 (C.C.E.D. Pa. 1823) (No. 3230) (Washington, J., riding circuit). 
such rights. The objections to using the Due Process Clause are familiar: it's the Due Process Clause (not the Due Liberty Clause). On this view, the government may treat everyone poorly, provided it follows established procedures for doing so. The objections to using the Equal Protection Clause to protect fundamental rights essential to national citizenship are also familiar: it's the Equal Protection Clause (not the Just Protection Clause). On this view, the government could satisfy its requirements by treating everyone equally unjustly.

What would happen if we were to overrule Slaughter-House and revive the Privileges or Immunities Clause as an alternative basis for protecting fundamental rights essential to national citizenship? Let's imagine that Balkin, a new originalist concerned with fidelity to the original public meaning of the Privileges or Immunities Clause, were to propose that we reconceive all of the substantive due process and fundamental rights equal protection cases as instead interpretations or constructions of the Privileges or Immunities Clause. (In fact, he has made an argument along such lines. ${ }^{40}$ )

I imagine that some readers are thinking that originalists like Scalia could never again object to protecting substantive fundamental rights on the ground that the Due Process Clause is the Due Process Clause, ${ }^{41}$ for the Privileges or Immunities Clause does not contain any language to suggest that it would protect only processual fundamental rights. And II suppose that some readers are thinking as well that Scalia could never again object to protecting unenumerated fundamental rights as such, on the ground that they are unenumerated. ${ }^{42}$ After all, the Privileges or Immunities Clause does not purport to enumerate the fundamental rights essential to national citizenship, such that we might infer that if an asserted fundamental right is not enumerated it is not protected (leaving aside the Ninth Amendment).

Well, think again. I daresay that Scalia would argue that the Privileges or Immunities Clause protects only processual rightshe would argue that the character of our democratic system entails that, in the absence of express constitutional provisions, the Constitution protects only processual rights. And I daresay

40. BALKIN, supra note 8, at 183-219.

41. See, e.g., Lawrence, 539 U.S. at 592 (Scalia, J., dissenting).

42. See, e.g., Planned Parenthood, 505 U.S. at 980 (Scalia, J., concurring in the judgment in part and dissenting in part). 
that Scalia would still object that because the Privileges or Immunities Clause does not enumerate the rights it protects, Justices are obligated to ignore it, as if its meaning had been "obliterated past deciphering by an inkblot," to recall Bork. ${ }^{43} \mathrm{He}$ would read the evidence of the original public meaning through the lens of his prior jurisprudential assumptions and commitments about the character of our constitutional rights (as enumerated and processual) as well as about the character of interpretation (to be interpretable, a provision must enumerate its contents and it must be rule-like rather than abstract principle-like).

And so, notwithstanding a hypothetical overruling of Slaughter-House, the arguments about what fundamental rights of national citizenship the Constitution protects through the Due Process Clause, the Equal Protection Clause, and the Privileges or Immunities Clause would likely go on much as before.

I want to make a final point about what the world probably would look like if we were to overrule Slaughter-House, revive the Privileges or Immunities Clause, and commit to carrying out its original public meaning. Justice Clarence Thomas indicated his openness to doing just that in dissent in Saenz v. Roe. Indeed, he stated there that Slaughter-House's gutting of the Privileges or Immunities Clause has contributed to what he sees as the disarray of Fourteenth Amendment jurisprudence. ${ }^{45}$ As I interpret his dissent, he would overrule all of the substantive due process cases, overrule all of the fundamental rights equal protection cases, and interpret the Privileges or Immunities Clause in light of his conception of its original public meaning. What do you suppose Thomas would interpret the Privileges or Immunities Clause to protect? I would expect primarily economic liberties of the sort Justice Field in dissent in Slaughter-House expected it to protect, and of the sort that the Supreme Court protected under the Due Process Clause during the era of Lochner. ${ }^{46}$

The larger point here, again, is that there is no definitive original public meaning of the Privileges or Immunities Clause that, if only we could recover it, would enable us to proceed in constitutional interpretation or construction without the

43. BORK, supra note 11 , at 166 .

44. Saenz v. Roe, 526 U.S. 489, 527-28 (1999) (Thomas, J., dissenting).

45. Id.

46. Lochner v. New York, 198 U.S. 45 (1905); Slaughter-House Cases, 83 U.S. 36, 96-97 (Field, J., dissenting). 
disagreements that we presently have. Conservatives like Thomas would argue for one set of privileges or immunities of national citizenship; liberals would argue for another. Both would do so in the garb of fidelity to original public meaning. Both would argue that their interpretations are, as Balkin puts it, necessary to redeem the promises of the Constitution. Disagreement about what fundamental rights are essential to national citizenship would continue, much as before, only now under the Privileges or Immunities Clause as well as under the Due Process and Equal Protection Clauses. Disagreement about the basic character of the Constitution, constitutional interpretation, and constitutional amendment would continue much as before. The debate, under the guise of arguments about fidelity to original public meaning, is a debate among competing moral readings of the Constitution. Any quest for original public meaning that seeks to deny or avoid the moral reading of the Constitution is misconceived.

\section{THE PROSPECTS FOR RECONCILIATION BETWEEN THE NEW ORIGINALISM AND LIVING CONSTITUTIONALISM (OR MORAL READINGS)}

What are the prospects for reconciliation between originalism and living constitutionalism? There is no hope regarding the old originalism and even reasonable versions of living constitutionalism (p. 67). Again, according to Solum, the old originalists believe that interpretation is determinative and construction is illegitimate (p. 68). Solum holds out the possibility of a "compatibilism" between new originalism and certain reasonable versions of living constitutionalism (pp. 6769). There would be agreement in broad terms concerning interpretation in the core and construction in the penumbra (pp. 67-68). There might be disagreement about how construction should be carried out. But there might be broad agreement about our constitutional practice as including multiple modalities as mentioned above. And there might be broad agreement in support of Balkin's living originalist method of text and principle.

The prospects for reconciliation of the new originalism and moral readings might be more promising. Again, many versions of living constitutionalism, with their pragmatic, instrumentalist, and forward-looking attitudes, along with their views of radical indeterminacy, are deeply at odds with originalism, however conceived. But moral readers like Dworkin and I reject the 
pragmatic, instrumentalist, and forward-looking attitudes, as well as the radical indeterminacy, of such versions of living constitutionalism. ${ }^{47}$ In these respects, such moral readers have affinities with Solum's new originalism. And I have already shown the general affinities between the new originalism and moral readings concerning interpretation and construction.

As evidence that the new originalists might view moral readers as good candidates for reconciliation, consider the following. Balkin's living originalism, which is a form of new originalism, is also a moral reading. ${ }^{48}$ Whittington has interpreted Dworkin's theory as a form of abstract originalism. ${ }^{49}$ Solum himself, in criticizing what he calls Dworkin's view of the "unity of interpretation," constructed an "alternative Dworkin" who for all intents and purposes is a new originalist who accepts the interpretation-construction distinction. ${ }^{50}$ Finally, Barber and I allowed our philosophic approach to constitutional interpretation to be characterized as an abstract originalism."

I venture to suggest that Solum's reasonable, programmatic, and inclusive manifesto has made the new originalism the best it can be; as such, it is amenable to reconciliation with a moral reading that interprets the Constitution so as to make it the best it can be.

\section{THE MISSING ARGUMENT FROM CONSTITUTIONAL PERFECTIONISM (OR FROM THE ASPIRATION TO FIDELITY TO OUR IMPERFECT CONSTITUTION)}

Finally, I want to make explicit the missing (or implicit) argument for the new originalism from constitutional perfectionism: an argument rooted in the aspiration to fidelity to our imperfect Constitution. Making this argument will further demonstrate the promise for a reconciliation of the new originalism and moral readings. Unlike many originalists, who

47. See BARBER \& FLEMING, supra note 10, at xiii (agreeing with Dworkin's moral readings approach); DWORKIN, supra note 5, at 7-8 (arguing for the moral reading as the "natural [or faithful] reading" of the Bill of Rights).

48. Fleming, supra note 29, at 675-79 (interpreting Balkin's "living originalism" as a moral reading of the Constitution).

49. Keith E. Whittington, Dworkin's "Originalism": The Role of Intentions in Constitutional Interpretation, 62 REV. POL. 197, $201(2000)$ (interpreting Dworkin as an "originalist" who argues that the Founders chose abstract principles). (2010).

50. Lawrence B. Solum, The Unity of Interpretation, 90 B.U. L. REV. 551, 567-77

51. BARBER \& FLEMING, supra note 10 , at 82-83, 99. 
practically assume that originalism-by definition, or axiomatically - is the only legitimate approach to constitutional interpretation, ${ }^{52}$ Solum acknowledges the need to make normative arguments for originalism (pp. 36-38). He stresses the normative arguments that originalism is more compatible with the rule of law and popular sovereignty than competing theories (pp. 38-44).

But Solum's formulation of the new originalism undercuts both of these arguments. First, his concessions that interpretation underdetermines outcomes, and that the development of doctrine occurs in the construction zone, undermines his rule of law argument that only originalism "guarantees a stable core of constitutional doctrine" (p. 41). Indeed, on his account, the development of doctrine takes place in the construction zone, and originalism does not provide a theory of construction (p. 69). Second, Solum's ideas about how we develop doctrine in the construction zone also undermines his popular sovereignty argument for originalism. For it turns out that "We the People" when ratifying the Constitution in 1791 or ratifying the Fourteenth Amendment in 1868 did not adopt determinative answers to our questions (p. 42). And so, in constructing doctrine, the new originalists are not simply following the rules laid down by "We the People" (p. 42). Thus, even on Solum's account, the decisions made by the popular sovereign in the past are underdeterminative; to that degree, the argument for originalism from popular sovereignty is attenuated.

Balkin's new originalism stresses a normative argument from the aspiration to fidelity to our imperfect Constitution. He recognizes that the Constitution in practice is highly imperfect; yet he argues that we should interpret it so as to redeem our faith in its promises and aspirations. ${ }^{53}$ Solum should make such an argument as well. A form of this argument may be implicit in his discussion of the Constitution, imperfections, and injustice. As he sees it, we have an imperfect Constitution. It is not so unjust that we should override the text of the Constitution in the name of doing justice; rather it is reasonably just (pp. 47-50). In concluding, I shall suggest that the type of theory he needs for this very circumstance of a reasonably just but imperfect Constitution is what I call a theory of fidelity to our imperfect

\footnotetext{
52. For a criticism of originalists who evidently take it as axiomatically given, see $i d$.

53. BALKIN, supra note 8 , at 74-81.
} at $104-07$. 
Constitution. ${ }^{54}$ Such a theory aspires to interpret and construct the Constitution so as to make it the best it can be (as Dworkin and I put it), ${ }^{55}$ or so as to redeem the promises of the (abstractly conceived) original public meaning (as Balkin puts it). ${ }^{56} \mathrm{~A}$ new originalism that incorporated such a conception of fidelity would be a new originalism that would be compatible with the best form of living constitutionalism - as we see it is in Balkin's living originalism. Such a new originalism also would be compatible with a moral reading of the sort that Dworkin has developed, that Barber and I have advanced in Constitutional Interpretation: The Basic Questions, and that I am pursuing in my book in progress, Fidelity to Our Imperfect Constitution. ${ }^{57}$ Solum cites my piece that previews this argument: "Fidelity to Our Imperfect Constitution" (p. 184 n.69), but he does not explicitly do anything with such an argument.

Solum might object that making such an argument would make the new originalism a form of perfectionism (a type of theory against which originalism defines itself). ${ }^{58}$ But we should distinguish, with Cass Sunstein, between first-order perfectionism and second-order perfectionism. First-order perfectionism argues directly for interpreting or constructing the Constitution so as to make it the best it can be. Second-order perfectionism argues instead that adopting a particular theory of interpretation or construction-whatever it is-will make the Constitution the best it can be.

Even if Solum is not prepared to sign on with Dworkin and me in first-order perfectionism, he should be willing to sign on with Sunstein and make a second-order perfectionist case for his theory. Indeed, such an argument is implicit in what he says in making normative arguments for originalism from the rule of law and popular sovereignty. He strongly suggests that applying the new originalism will put our Constitution and constitutional practice in their best light. Solum should make the argument explicit: adopting the new originalism and applying it will make

54. James E. Fleming, Fidelity to Our Imperfect Constitution, 65 FORDHAM L. REV. 1335 (1997).

55. Id. at 1354

56. BALKIN, supra note 8 , at 3 .

57. BARBER \& FLEMING, supra note 10; DWORKIN, supra note 5; FLEMING, supra note 5 .

58. See Fleming, supra note 29 , at 670 (suggesting that the only thing that the many, balkanized varieties of originalism agree upon is their rejection of moral readings).

59. See Cass R. Sunstein, Second-Order Perfectionism, 75 FORDHAM L. REV. 2867, $2867-70(2007)$. 
the Constitution and our constitutional practice the best they can be.

At a minimum, Solum could leave it at that. Or, he could embrace Balkin's method of text and principle, which is a firstorder perfectionist approach that would interpret and construct the Constitution so as to redeem the promises of its commitments. In doing so, he would put forward a new originalism that is compatible with a moral reading or Constitution-perfecting theory. That would be the best new originalist approach for pursuing the aspiration to fidelity to our imperfect Constitution. 